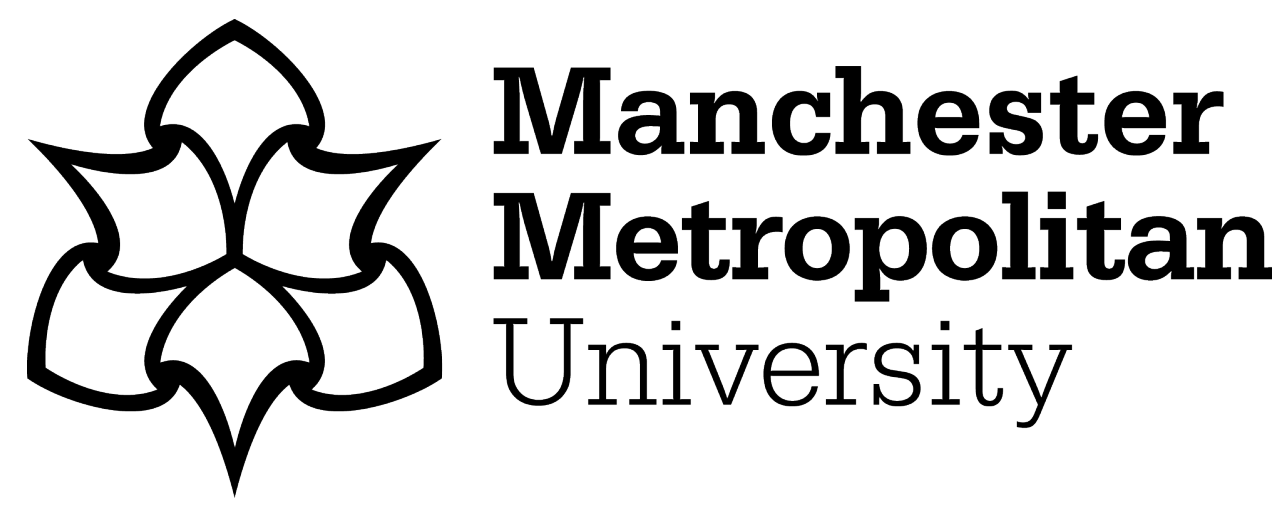

Venkatraman, Prabhuraj ORCID logoORCID: https://orcid.org/0000-00034290-4510, Sayed, Usha, Parte, Sneha and Korgaonkar, Swati (2021) Consumer Perception of Environmentally Friendly Antimicrobial Textiles: a case study from India. International Journal of Advanced Science and Engineering, 7 (3). pp. 1782-1793.

Downloaded from: https://e-space.mmu.ac.uk/627431/

Version: Published Version

Publisher: Mahendra Publishers

DOI: https://doi.org/10.29294/IJASE.7.3.2021.1782-1793

Usage rights: Creative Commons: Attribution-Noncommercial-Share Alike 4.0

Please cite the published version 


\title{
Consumer Perception of Environmentally Friendly Antimicrobial Textiles: a case study from India
}

\author{
Prabhuraj D.Venkatraman ${ }^{1 *}$, Usha Sayed ${ }^{2}$, Sneha Parte ${ }^{2}$, Swati Korgaonkar ${ }^{2}$ \\ ${ }^{1}$ Manchester Fashion Institute, Faculty of Arts and Humanities,Manchester Metropolitan University [MMU], \\ Cavendish Street, Manchester, M15 6BG, United Kingdom \\ ${ }^{2}$ Department of Fibres and Textile Chemistry,Institute of Chemical Technology [ICT], Nathalal Parekh Marg, \\ Matunga, Mumbai 400 019, India
}

ABSTRACT:The recent global pandemic and an increasing awareness for hygiene led to changes in consumers' behaviour towards their health and wellbeing. Owing to growing consumers' knowledge on environmental impact of textiles, especially those who are health conscious and living in cities, it becomes vital to explore their perception towards antimicrobial textiles. This study investigated the consumer perception and specific requirement of sustainable antimicrobial textiles. A cross-sectional questionnaire survey was conducted online and collated from 306 participants (Female 49.3\%; Male 50.6\%) of five main cities in India including Delhi, Mumbai, Kolkata, Bengaluru, and Chennai. The majority of participants were healthcare workers and academics with an average age of $32 \pm 7$ (6.6 standard deviation).The questionnaire had high internal consistency and reliability, and the factor analysis indicated 15 items relating to four attributes were relevant to extract information from the community on environment-friendly antimicrobial textile. The findings show that consumer's awareness of rural heath, hygiene and environmental issues could influence the purchase of sustainable antimicrobial textiles made of organic fibres with herbal finish. The consumers believe that by purchasing sustainable product they contribute towards the society. This is the first study to report on consumers' preferences for sustainable antimicrobial textiles and contributes to the literature by developing a scale with high reliability that is community-relevant, consumercentered, and product-specific. This research underscores the importance of consumers' awareness, knowledge, and preference of environmentally friendly antimicrobial hygiene textiles. The outcomes will benefit various stakeholders [healthcare workers, industry, and community] in promoting environmental-friendly and sustainable products among consumers in India.

KEYWORDS: India, Consumer perception, Rural health, Product related attributes, Antimicrobial textiles, Sustainable clothing.

\section{INTRODUCTION}

The use of antimicrobial textiles to prevent the growth of microorganisms and protect from infection [1] through surface contact or from the environment has been high owing to current global pandemic. The major governmental and non-governmental institutions have been recommending the use of personal hygiene wear to protect each other from the spread of infections while commuting or in close proximity with other people. There are reports [2] about the need to improve sanitation facilities in the rural community of India and as sanitation affects those in marginalized sections who have greater risk of communicable diseases [3]. The vector bites could carry diseases like malaria, dengue, which can be prevented by wearing long sleeves and trousers or applying insect repellents [4].

In recent times, to alleviate the impact of environment and the society from synthetic chemicals, several eco-friendly initiatives in India [organic cotton clothing range [5], brands like Fabindia, Khadi India] have been promoted. Globally, consumers have shown interest to purchase ecofriendly products [6], and would prefer their ecofriendly products to be durable, long lasting, made of good quality [7]. In addition to fulfilling ethical and eco-friendly credentials, the color, fit, style, and quality of products should be appealing to the consumers [7]. Such green products should also be designed based on consumer preferences and resulting in a sustainable design innovation [8]. The consumers' ethical commitment and values are some of the drivers for purchasing eco-clothes and ecomaterials that represent a specific market [7]. It added that manufacturers, designers, and retailers were not aware of consumer expectations of the ecoclothing and that could be resulting in a gap within the eco-fashion field [7].

*Corresponding Author:p.venkataraman@mmu.ac.uk

Received: $18.11 .2020 \quad$ Accepted: 19.01 .2021

Published on: 22.02.2021

Venkatraman et al., 
Some studies have shown that youth are more concerned about the environmental impact of clothing, ethical and safety issues; among them women are more concerned than men. The other product related concerns include short life span of product and low quality. It also suggests that consumers' dissatisfaction lies in low quality and thus the manufacturers should focus on product longevity and inform users on how many washes will the product last and look aesthetically good. This information will enable the consumers to make suitable decisions and connections to price, quality, and their usefulness [9]. Hence, it becomes vital to understand consumers' perception. Kang et al. reported that the consumers' [participants from US, Korea, and China] product knowledge, their effectiveness and relevance affect young consumers' attitudes and their purchase intentions towards environment-friendly sustainable textiles [10].

It is interesting to note that consumers in Hawaii market were happy to pay higher premium for clothing made of organic cotton [11]. However, in India, such organic clothing that is expensive bearing environment-friendly credentials usually claimed by a manufacturer is chosen by consumers only if they are certified by a third-party organization [12]. The urban Indian communities (mostly post-graduate professionals) with improved awareness on environmental consciousness (labelled as 'dark green apparel' consumers) were content with paying more for eco-labelled clothing [13]. Indian youth generally prefer style, fit, variety, comfort, durability, and colour as some of the product attributes when deciding to purchase apparel; and women tend to buy more items per year than men [14]. The Indian youths' buying behaviour of organic clothing can be influenced by factors including social influence, past behaviour, peer influence, and apparel knowledge. It was also noted that peer influence and consumers' knowledge had no influence on buying organic apparel [15].The studies also reveal that youth consumers in India have an intention to purchase green apparel as they are influenced by social activities and engage with brands associated with green apparel [16].Although consumer buying behaviour of eco-friendly clothing were noted over the last decade or so, a little attention was paid on how consumers' choice and preference differ towards antimicrobial textiles to improve selfhygiene.

This project is a part of the Global Challenges Research Fund [GCRF], which aims to support a rural community in a developing country [Mumbai, India] by improving the health and well-being using locally grown resources to develop sustainable and environment-friendly antimicrobial products to improve hygiene. The present study reports on the consumer perception of Indian community towards the usage of antimicrobial or hygiene textiles, based on various attributes. Based on these set of attributes, there search describes consumers' perception that will facilitate various stakeholders during design, development, and promotion of such eco-friendly antimicrobial textiles. To authors' knowledge, this is the first demonstration of evaluating consumers' preferences relating to development of environmentfriendly antimicrobial textiles. The aim of this present work is to address this void in the literature by evaluating the consumers' preference of sustainable and environmentfriendly antimicrobial and their requirement of sustainable hygiene products.

\section{Background and rationale}

Textiles are treated with antimicrobial agents, which prevent the growth of microorganisms and protect from further infection. Antimicrobial chemical or material can either inhibit bacterial cell growth called as biostatic effect or can kill the microorganisms - biocidal [1,17]. Most of the antimicrobial agents used in textiles are biocides [18]. As humans, we have continuous contact with fabrics where virus or microbes can survive, which increases the chances of spreading infection. Due to the recent pandemic and the rise in awareness of prevention of air-borne, communicable diseases and infection acquired during travel or from hospitals, the market for antimicrobial textiles is bound to grow and would reach $\$ 12.3$ bn by 2024 at a compounded annual growth rate [CAGR] $5.4 \%$ between 2019 and 2024 [19]. Several companies have begun to take advantage of this global pandemic and focus on developing antibacterial or anti-microbial fabrics.

The anti-viral fabrics and anti-bacterial finished fabrics although available in developed countries, are not widely available in India and the market is gradually taken over by many industries like Arvind Ltd., Donear Industries, Welspun India Ltd., and Vardhman Textiles. Donear industries in collaboration with HeiQ, a Swiss firm reported on the development ofa textile that has resistance to harmful virus [20]. Other recent developments include, Siyaram, a leading textile brand in India popular for shirting and dress materials reported the anti-corona fabric, in collaboration with Health Guard from Australia, which could kill MRSA [Methicillin resistant Staphylococcus aureus], and effective against coronavirus. It claims to be durable against multiple washes and replenished using a spray or padding method [21]. Trident group of companies popular for home textiles are also developing hygiene textiles like masks, antimicrobial,

\section{Venkatraman et al.,}


and odour neutralizing bed sheets for the domestic market [22].

It was reported that the poorest of the poor and marginalized sections of the society in India are at greater risk of communicable diseases and are least capable to cope with the diseases [3]. Only $21 \%$ in rural India use improved sanitation facilities [2]. The hygiene in rural India is poor. Cochrane review [23] stated that hand washing could reduce the incidence of diarrhea by about $30 \%$ mainly among those in lowmiddle income countries and high-income countries. The vector borne diseases [mosquitoes] are bound to affect the region and it is of great concern in India [3]. WHO reported that a bite of a vector could carry diseases like malaria, dengue, Lyme disease, etc., and it can be prevented by wearing shirts with longsleeves and trousers and applying insect repellent amongst many other prevention methods [4]. In addition, there is a great disparity for those who live in urban and rural areas of India. Therefore, it is proposed that use of naturally made antimicrobials could serve as a repellent, prevent vector/insect bites, and reduce the spread of infections or vector borne diseases.

The fashion-conscious youth in India is a growing market as they are attracted to global and latest fashion apparel. India is projected to witness a marginal decrease in the youth population, where $50 \%$ of Indians are 25 years or older [24]; it was noted that population in the age group of 15-34 years will increase to 464 million in 2021 from 430 million in 2011[25] and is also projected to see a drop in the growth of younger population after 2026 to 458 million. Recent studies [26], [27] reported on Indian youth's buying behaviour of green clothing. The research is looking at whether previous environmentfriendly related behaviour or peer influence or organic clothing knowledge had any influence on consumer's (Indian youth) purchase behaviour. It has shown that the past environment-friendly buying attitude or one's own belief or experience of using a product has a significant effect on the purchase of organic clothing [27]. Researchers suggested promoting organic clothing as premium product, with effective marketing strategies highlighting the benefits of organic apparel that would increase awareness. Khare et al. [28] reported the effect of consumers' knowledge, materialism, product availability for predicting consumers organic clothing purchase. The consumers' knowledge and past involvement with the product influenced organic clothing purchase. The price and availability of organic clothing as a fashionable item served as a factor for consumers to get involved in organic clothing purchase. It is interesting to note that consumers from India support Corporate Social
Responsibility (CSR), and believe that awareness and education relating to socially responsible firms is pertinent in decision making process. The price and the quality of sustainable products are important factors, even if a company is socially responsible but do not offer good quality products, then the customers are less likely to buy from it. The consumers in India believe that the firms should gain their trust initially and ensure price and quality comparatively, and make their products be available in the market [29].

According to Cotton Incorporated's Global Lifestyle monitor survey [30], India is predicted to become the world's third largest apparel market with a huge spending on clothes by 2030, next to China and USA, where $91 \%$ of Indians enjoy shopping as compared to $63 \%$ in EU and $52 \%$ in USA. Some of the product attributes including colour, durability, fit, style, and quality are the drivers for purchase. The consumers in India are generally aware of environmental and social impact - relating to water shortage (87\%), food scarcity (87\%), urbanization (87\%), and depletion of natural resources (86\%) and are more likely to support sustainable clothing. The consumers feel cotton is safe for the environment than synthetic fibres; and when it comes to cotton, they are more likely to be worried by usage of chemicals, pesticides, water usage, and greenhouse gas emissions. Owing to concerns on environmental and societal impact, an initiative to support organic cotton-based products is beginning to grow in the Indian sector [27]. While buying organic apparel, fabric softness was reported as one of the factors influencing organic product purchase [31].

However, it was also interesting to note that consumers opting to buy products made of sustainable materials or organic clothing are still in a nascent stage[28] although owing to recent pandemic, there is an urge towards the increasing awareness of hygiene textiles to improve one's health. The scientific literature reporting [32-36] on the development of herbal based antimicrobials is seldom widely available for consumers to purchase and there is less literature on the consumer perception and buying attitudes of antimicrobial products in India. Therefore, the primary purpose of this research was to examine the consumer preference towards sustainable and eco-friendly hygiene products and gain insights on their specific preferences which have implications for manufacturers, retailers, and professionals in this field to increase awareness and meet consumers' demand. Based on the above, the authors posit the following hypotheses - H1: Consumers concern with health within the community affects their awareness to improve hygiene; H2: Increased community knowledge encourages consumers' hygiene product preferences and H3:

Venkatraman et al., 
Consumers in the community have specific preferences in the hygiene product.

\section{Research Objectives}

1. To investigate the current knowledge/awareness of consumer on rural health and issues in the community.

2. To explore the consumer's preferences on the usage of antimicrobial products such as wipes or textiles to improve self-hygiene.

3. To understand whether consumer's awareness on sustainable and environment-friendly textiles have specific preference on products.

4. To identify consumers' specific requirements (product related attributes) of using an antimicrobial textile.

\section{METHODS}

Survey questionnaire:

To ascertain community and consumer perception of health issues and preferences of the product a close-end questionnaire was developed with a 7- or 5point likert scale that produces data on a continuous scale (ordinal data). Responses variables were coded on a scale 1-5 or 7, where 1 refers to 'strongly agree'; 7 or 5refers to 'strongly disagree'. As there was little information on consumers' preference on purchasing eco-friendly antimicrobials, a survey was developed in this research. There were four constructs comprising of 25 items in the survey: 1). health and hygiene attributes, 2). Community preferences of the product; 3). product preferences, and 4). importance of physical attributes (see Table 1 for further details on the survey). All participants were offered information about the contents of the survey and about the project and all the participants offered their consent for research analysis. Data was anonymously collected, and the survey was distributed online following University Ethics approval -Ethos Ref. 20187/0503. The data analysis was carried out using SPSS Ver. 26.0 and AMOS 24.0 for determining the structural equation model.

\section{Participant characteristics}

A convenience sampling method was used to approach participants using a 'Google online form' that was distributed via social network from authors' contact list to five major cities across India. The survey was open for five weeks and it comprised of 306participants (Female 151; Male 155) from five main cities in India including Delhi (61; 24-Male/37Female), Mumbai(100; 55-M/45-F), Kolkata (52; 18$\mathrm{M} / 34-\mathrm{F})$, Bengaluru $(44 ; 24-\mathrm{M} / 20-\mathrm{F})$ and Chennai(49; $32-\mathrm{M} / 17-\mathrm{F}$ ) that also covered city as well as outer regions. The participants were from various back ground that included 115 healthcare workers or physicians; 53 were academics, 46 were from junior level academics or health workers, 46 were middle management from industry, 45 executives and one student. The participants were aged between $20-50$ with an average age of 32 years \pm 7 (6.6 standard deviation). Most of the participants had Master's qualification $(n=111)$, while some had Bachelor's degree $(n=86)$, and the remaining PhD $(n=84), P G$ diploma $(n=12)$. A very few were from Higher secondary $(n=11)$ and junior level college $(n=2)$ qualification.

\section{Table 1 Survey questionnaire}

\begin{tabular}{|c|c|c|}
\hline Construct & Items (5- or 7-point likert scale) & Purpose \\
\hline $\begin{array}{l}\text { Health attributes and } \\
\text { hygiene issues }\end{array}$ & $\begin{array}{l}\text { 1. Individual hygiene in rural community } \\
\text { 2. Infections in the community } \\
\text { 3. Common type of infections } \\
\text { 4. Rise of skin disorder or dermatitis in India }\end{array}$ & $\begin{array}{l}\text { To examine the consumers' } \\
\text { current knowledge on } \\
\text { infections, their concerns, } \\
\text { and effect on the society }\end{array}$ \\
\hline $\begin{array}{l}\text { Community preferences } \\
\text { of use of antimicrobial } \\
\text { product }\end{array}$ & $\begin{array}{l}\text { 1. Hygiene fabrics with herbal extract reduce } \\
\text { infections } \\
\text { 2. Requirement of antimicrobial product } \\
\text { 3. Frequency of use of antimicrobial product } \\
\text { 4. Size of the product } \\
\text { 5. Product usage } \\
\text { 6. Preference of environment-friendly products } \\
\text { 7. Purchase sustainable product } \\
\text { 8. Perception of contribution to the society when } \\
\text { buying environment-friendly products }\end{array}$ & $\begin{array}{l}\text { To extract user knowledge } \\
\text { and preferences, } \\
\text { requirements on } \\
\text { antimicrobial products as } \\
\text { well as their view on buying } \\
\text { sustainable products, which } \\
\text { are environment-friendly }\end{array}$ \\
\hline $\begin{array}{l}\text { Specific preferences of } \\
\text { antimicrobial textile }\end{array}$ & $\begin{array}{ll}\text { 1. } & \text { Reusable preference } \\
\text { 2. } & \text { Product price } \\
\text { 3. Easy to dispose and biodegradable } \\
\text { 4. Wash and reusability } \\
\text { 5. } \\
\end{array}$ & $\begin{array}{l}\text { In this section, the } \\
\text { questionnaire examines } \\
\text { practical issues of product } \\
\text { consumption, usability, price, } \\
\text { material composition and }\end{array}$ \\
\hline
\end{tabular}

Venkatraman et al., 


\begin{tabular}{|c|c|c|}
\hline & & disposability. \\
\hline $\begin{array}{l}\text { Physical aspects of the } \\
\text { antimicrobial product } \\
\text { (product related } \\
\text { attributes) }\end{array}$ & $\begin{array}{l}\text { 1. Possess strength and durability } \\
\text { 2. Product to be stretchable } \\
\text { 3. Soft and comfortable } \\
\text { 4. Highly moisture absorbent } \\
\text { 5. Made of organic fibres } \\
\text { 6. Product stays fresh } \\
\text { 7. Product with soft texture } \\
\text { 8. Antimicrobial finish for clothing }\end{array}$ & $\begin{array}{l}\text { Final part of the survey looks } \\
\text { at specific attributes of the } \\
\text { product's features such as } \\
\text { durability, ability to absorb } \\
\text { moisture, finish, texture, type } \\
\text { of fibre blends, etc. }\end{array}$ \\
\hline
\end{tabular}

\section{RESULTS}

Cronbach's alpha measures the reliability of the internal consistency of items in the questionnaire. The analysis shows the overall Cronbach's alpha was 0.875 $(\mathrm{n}=25$ items) and alpha based on standardized items was 0.886 , indicating high reliability of items in the questionnaire. Analysis revealed that when items 1, 14, 16 and 20 were removed alpha improved marginally, however, when the remaining other items were removed, Cronbach's alpha reduced marginally (Table 2). Therefore, based on this analysis, it is recommended to retain all the items of the questionnaire.
Cronbach's alpha is used to assess the reliability of the instrument, alpha above 0.7 are considered good [3739]. The above analysis reveals a high reliability of questionnaire. Table 2 also shows the average score for all the items. The average item score range was 1.2 to 2.9 indicating that consumers either strongly agree or agree to most of the items enquired via the questionnaire. Contrasting to the above, an item was scored $3.88 \quad( \pm 1.3 \mathrm{SD})$ indicating that consumers neither prefer a product that is stretchable nor with high stretch.

Table 2 Cronbach's alpha - reliability of items in the questionnaire

\begin{tabular}{|c|c|c|c|c|}
\hline Order & Item & Mean & S.D. & $\begin{array}{l}\text { Cronbach's } \\
\text { Alpha if Item } \\
\text { Deleted }\end{array}$ \\
\hline 1 & Individual hygiene in rural community & 1.75 & 1.28 & 0.88 \\
\hline 2 & Infections in the community & 1.64 & 0.88 & 0.87 \\
\hline 3 & Common type of infections & 1.94 & 1.37 & 0.87 \\
\hline 4 & Skin disorder or dermatitis are on a rise in India & 2.18 & 0.62 & 0.87 \\
\hline 5 & Hygiene fabrics with herbal extract & 1.51 & 0.75 & 0.87 \\
\hline 6 & Requirement of antimicrobial product & 1.19 & 0.51 & 0.87 \\
\hline 7 & Frequency of use antimicrobial product & 2.55 & 0.99 & 0.87 \\
\hline 8 & Smaller size of the product & 1.52 & 0.78 & 0.87 \\
\hline 9 & Using the product & 2.20 & 0.77 & 0.87 \\
\hline 10 & Product that is environmentally friendly & 2.20 & 0.77 & 0.87 \\
\hline 11 & Reusable preference & 1.94 & 0.84 & 0.87 \\
\hline 12 & Product price - economical & 1.30 & 0.77 & 0.87 \\
\hline 13 & Easy to dispose and biodegradable & 1.60 & 0.72 & 0.87 \\
\hline 14 & Wash and reuse & 2.17 & 0.64 & 0.88 \\
\hline 15 & Preference of synthetic & 2.34 & 0.86 & 0.87 \\
\hline 16 & Possess strength and durability & 2.40 & 0.92 & 0.88 \\
\hline 17 & Product stretchable & 3.88 & 1.31 & 0.87 \\
\hline 18 & Soft and comfortable & 1.24 & 0.62 & 0.87 \\
\hline 19 & Highly moisture absorbent & 1.20 & 0.62 & 0.87 \\
\hline 20 & Made of organic fibres & 1.66 & 0.68 & 0.88 \\
\hline 21 & Purchase sustainable product & 1.83 & 1.04 & 0.86 \\
\hline 22 & Contribute to the society & 1.74 & 0.92 & 0.86 \\
\hline 23 & Product stays fresh & 2.10 & 0.59 & 0.87 \\
\hline 24 & Antimicrobial clothing & 2.17 & 0.68 & 0.87 \\
\hline 25 & Product with soft texture & 1.27 & 0.55 & 0.87 \\
\hline
\end{tabular}

\section{Explanatory Factor analysis}

The Principal Component Analysis (PCA) was conducted after assessing their suitability on 25 -item questionnaire that evaluated consumer's knowledge of community rural health and spread of infections and their specific requirement of antimicrobial textiles on 306 participants. All the 15 variables had at least one correlation coefficient greater than 0.3 , which was 
observed using correlation matrix and remaining 10 items (less than 0.3 correlation coefficient) were removed. Kaiser-Meyer-Olkin (KMO) was 0.81, with individual KMO measures all in the range 0.69 to 0.88 . It is reported that KMO above 0.8 is considered meritorious [40].It also reveals that sample size was large enough to assess the factors. Bartlett's test of sphericity was significant, $\mathrm{p}<0.0005$, (with $\chi^{2}-2035$, df -105) indicating that the factorizability of correlation matrix [40], [41].All the items had communalities above 0.4 , any lower value below 0.3 suggests removal of the item [40] [42] [43]. Principal component analysis showed four components with eigen values more than one, that explained $31.9 \%, 15.5 \%, 9.5 \%$, and $7.5 \%$ of the total variance, respectively. Scree plot (Fig. 1) shows the total variance extracted by each component in the questionnaire, and it revealed that four components should be retained, the point where the line graphs level out as shown.

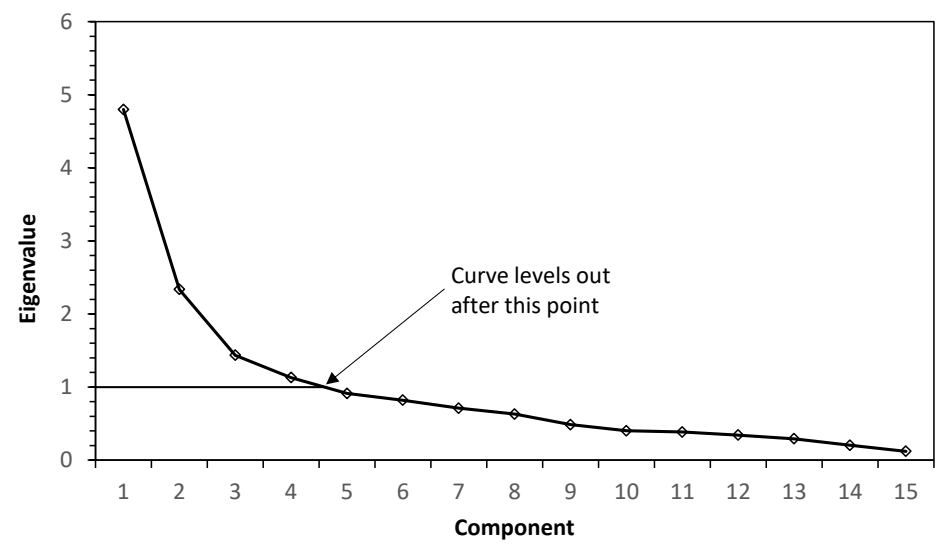

Figure 1 Scree plot - factor analysis

Table 3 Rotated matrix structure for PCA with varimax rotation

\begin{tabular}{|c|c|c|c|c|c|}
\hline \multirow[t]{2}{*}{ Items } & \multicolumn{4}{|c|}{ Component } & \multirow[t]{2}{*}{ Communalities } \\
\hline & 1 & 2 & 3 & 4 & \\
\hline Purchase sustainable product & 0.74 & -0.11 & -0.32 & -0.11 & 0.68 \\
\hline Contribute to the society & 0.73 & -0.19 & 0.02 & -0.35 & 0.69 \\
\hline Easy to dispose and biodegradable & 0.72 & -0.14 & -0.17 & -0.32 & 0.67 \\
\hline Product that is environment-friendly & 0.67 & -0.21 & -0.32 & 0.23 & 0.64 \\
\hline Product price - economical & 0.62 & -0.23 & 0.44 & 0.09 & 0.64 \\
\hline Frequency of use antimicrobial product & 0.62 & -0.10 & -0.25 & -0.08 & 0.46 \\
\hline Requirement of antimicrobial product & 0.61 & -0.18 & 0.40 & 0.06 & 0.57 \\
\hline Antimicrobial clothing & 0.54 & -0.23 & -0.32 & 0.39 & 0.59 \\
\hline Hygiene fabrics with herbal extract & 0.47 & -0.06 & -0.15 & -0.39 & 0.41 \\
\hline Individual hygiene in rural community & 0.35 & 0.88 & -0.02 & 0.04 & 0.90 \\
\hline Infections in the community & 0.47 & 0.82 & 0.01 & -0.07 & 0.90 \\
\hline Common type of infections & 0.46 & 0.77 & 0.06 & 0.16 & 0.84 \\
\hline Preference of synthetic & 0.37 & -0.06 & 0.60 & -0.29 & 0.58 \\
\hline Reusable product preference & 0.42 & -0.13 & 0.54 & 0.36 & 0.61 \\
\hline Skin disorder is on a rise in India & 0.46 & -0.11 & -0.11 & 0.52 & 0.51 \\
\hline
\end{tabular}

The four-component solution explained $64.6 \%$ of the are presented in Table 3.Nine items were loaded on to total variance, component loadings and communalities factor 1 that relate to items of consumer awareness of 
sustainable product and preference on antimicrobial product usage; three items loaded on to factor 2 that related to rural health in the community and their awareness of community health; two items were loaded onto factor 3 that related to product related attributes and two further items for factor 4 that related to product reusability and awareness on rural health. The factor analysis had shown 15 items relating to four attributes identified earlier in the questionnaire were relevant to extract information from the community on environment-friendly antimicrobial textile.

\section{Structural equation model analysis}

Further to explanatory factor analysis, a structural equation model [SEM] was tested to determine the predictor variables towards the purchase of environmentally friendly hygiene textiles. Observed endogenous variables in the proposed model was related to community awareness on individual health, hygiene, and common infections in the society; preference to purchase sustainable product (made of organic fibres), perception of contribution to the society when buying sustainable products. Other variables include specific product preference - product being economical in price; easy to dispose and biodegradable. Final construct was related to specific product preference and it included hygiene fabrics be treated with herbal finish, frequency of using antimicrobial product and treatment be available for other apparel.

Chi-square test indicated a significance level $\mathrm{p}<0.001$, degree of freedom $=24, \chi^{2}$ value 51.44 . CMIN/DF-2.14(ratio values can vary from 3 to 1 for an acceptable fit - [44]); Model fit indices include: Goodness of fit index [GFI] - 0.96; AGFI [adjusted goodness-of-fit index]- 0.93; and comparative fit index [CFI] - 0.97. The Root Mean Square Error of Approximation [RMSEA] was 0.06 [values should be between $0-0.08$ [45]]. The above analysis indicates a good model fit using the data obtained from this study.

In the structural model (Table 4), select constructs from factor analysis were used, that included four latent variables and predictor variables to determine the model of fit. From the above analysis it can be noted that there is a positive relationship between consumers health and environmental concerns and their preferences for antimicrobial product that is sustainable; standardized path coefficients, $B=0.10$, $\mathrm{p}=0.014$, therefore, $\mathrm{H} 1$ was supported. Consumers awareness within the community also affected their product preferences relating to product durability, herbal finished hygiene products and clothing $(\beta=0.96$, $\mathrm{p}<0.00$ ), therefore, H2 was supported; similarly, consumers within the community also have specific product preferences of antimicrobial product that is economical, easy to dispose and biodegradable. $(ß=1.08, p<0.00)$ and $H 3$ was supported.

\section{Table 4 Structural equation model}

\begin{tabular}{|l|c|c|c|c|c|}
\hline Structural Model & $\begin{array}{c}\text { Path } \\
\text { coefficient }\end{array}$ & p value & $\begin{array}{c}\text { Regression } \\
\text { weight }\end{array}$ & Critical ratio & Results \\
\hline $\begin{array}{l}\text { Health awareness } \\
\rightarrow \text { community awareness }\end{array}$ & 0.10 & 0.014 & 0.22 & 2.45 & Supported \\
\hline $\begin{array}{l}\text { Community awareness } \rightarrow \\
\text { product preference }\end{array}$ & 0.96 & 0.000 & 0.96 & 7.8 & Supported \\
\hline $\begin{array}{l}\text { Community awareness } \rightarrow \\
\text { specific preference }\end{array}$ & 1.08 & 0.000 & 1.07 & 13.01 & Supported \\
\hline
\end{tabular}

A Mann-Whitney test was conducted to determine whether any differences exist among consumer preferences [based on gender - female/male] toward the selection of antimicrobial textiles, where preferences were measured using an ordinal variable. The distribution of scores for both the groups were evaluated for its shape and a 'similar shape' resulted in determining the differences in the medians of two groups [46]. Median preference scores for male and female participants were not statistically significant (See Table 5). Marginally differences between female and male participants also indicate that there is no variation in the perception of participants and their preferences on antimicrobial textiles remain alike. It could be observed that average value of each item is in the range 1 to 2 , which meant consumers either agree or strongly agree to the statement.

Venkatraman et al., 
Table 5 Consumer perception of antimicrobial textile -difference between male and female participants§

\begin{tabular}{|c|c|c|c|c|c|c|c|}
\hline \multirow{2}{*}{ Item } & \multirow{2}{*}{$\begin{array}{c}\text { Mann- } \\
\text { Whitney } \\
\text { U test }\end{array}$} & \multirow{2}{*}{$\begin{array}{c}\text { Z value } \\
\text { (95\% } \\
\text { CI) }\end{array}$} & \multirow{2}{*}{$\begin{array}{c}\text { Asymptotic } \\
\text { (2-tailed) } \\
\text { p-value }\end{array}$} & \multicolumn{2}{|c|}{ Median } & \multicolumn{2}{|c|}{ Mean } \\
\hline & & & & Male & Female & Male & Female \\
\hline $\begin{array}{l}\text { 1.Individual hygiene in rural } \\
\text { community }\end{array}$ & 10929 & -0.8 & 0.42 & 1 & 1 & 1.89 & 1.60 \\
\hline 2.Infections in the community & 10557 & -1.3 & 0.18 & 2 & 1 & 1.73 & 1.56 \\
\hline 3.Common type of infections & 11383 & -0.13 & 0.89 & 2 & 2 & 2.02 & 1.88 \\
\hline $\begin{array}{l}\text { 4.Skin disorder or dermatitis } \\
\text { are on a rise in India }\end{array}$ & 11315 & -0.33 & 0.73 & 2 & 2 & 2.20 & 2.15 \\
\hline $\begin{array}{l}\text { 5. Hygiene fabrics with herbal } \\
\text { extract }\end{array}$ & 10857 & -0.93 & 0.35 & 1 & 1 & 1.52 & 1.51 \\
\hline $\begin{array}{l}\text { 6. Requirement of } \\
\text { antimicrobial product* }\end{array}$ & 12089 & 1.27 & 0.20 & 1 & 1 & 1.17 & 1.21 \\
\hline $\begin{array}{l}\text { 7. Frequency of use } \\
\text { antimicrobial product }\end{array}$ & 11949 & 0.75 & 0.45 & 2 & 2 & 2.52 & 2.58 \\
\hline 8.Smaller size of the product & 12073 & 0.90 & 0.36 & 1 & 1 & 1.51 & 1.52 \\
\hline 9.Using the product* & 11390 & -0.151 & 0.88 & 2 & 2 & 2.19 & 2.20 \\
\hline $\begin{array}{l}\text { 10.Product that is } \\
\text { environmentally friendly }\end{array}$ & 11390 & -0.151 & 0.88 & 2 & 2 & 2.19 & 2.20 \\
\hline 11.Reusable preference & 11250 & -0.34 & 0.73 & 2 & 2 & 1.95 & 1.92 \\
\hline 12.Product price - economical & 11247 & -0.44 & 0.65 & 1 & 1 & 1.31 & 1.28 \\
\hline $\begin{array}{l}\text { 13.Easy to dispose and } \\
\text { biodegradable* }\end{array}$ & 11103 & -0.54 & 0.58 & 1 & 1.5 & 1.58 & 1.61 \\
\hline 14.Wash and reuse $\dagger$ & 10648 & -1.3 & 0.18 & 2 & 2 & 2.22 & 2.12 \\
\hline 15.Preference of synthetic & 10964 & -0.94 & 0.36 & 2 & 2 & 2.35 & 2.35 \\
\hline $\begin{array}{l}\text { 16.Possess strength and } \\
\text { durability }\end{array}$ & 11226 & -0.40 & 0.68 & 2 & 2 & 2.37 & 2.43 \\
\hline 17.Product stretchable & 10579 & -1.32 & 0.18 & 3 & 3 & 3.96 & 3.80 \\
\hline 18.Soft and comfortable* & 11321 & -0.32 & 0.75 & 1 & 1 & 1.24 & 1.24 \\
\hline $\begin{array}{l}\text { 19.Highly moisture } \\
\text { absorbent* }\end{array}$ & 11380 & -0.22 & 0.83 & 1 & 1 & 1.21 & 1.18 \\
\hline 20.Made of organic fibres & 11412 & -0.09 & 0.92 & 2 & 2 & 1.63 & 1.68 \\
\hline $\begin{array}{l}\text { 21. Purchase sustainable } \\
\text { product }\end{array}$ & 11259 & -0.31 & 0.75 & 2 & 2 & 1.87 & 1.80 \\
\hline 22. Contribute to the society & 11294 & -0.26 & 0.79 & 2 & 2 & 1.70 & 1.78 \\
\hline 23. Product stays fresh & 11415 & -0.13 & 0.89 & 2 & 2 & 2.10 & 2.09 \\
\hline 24. Antimicrobial clothing & 11433 & -0.08 & 0.93 & 2 & 2 & 2.17 & 2.16 \\
\hline 25. Product with soft texture & 11251 & -0.39 & 0.69 & 1 & 1 & 1.27 & 1.26 \\
\hline
\end{tabular}

§NOTE: Seven-point likert scale:1-Strongly agree; 2- agree; 3-somewhat agree; 4-neither agree or disagree; 5-somewhat disagree; 6-disagree; 7-strongly disagree; * Five-point likert scale- 1-always; 2-occassionally;3-sometimes;4-rarely and 5never; † Frequency of use: 1-more than five times; 5-only once.

The consumers were enquired about their awareness about the rural community health and infections. $96 \%$ of participants agreed that spread of infection can be prevented. $95.2 \%$ agreed that there are problems in individual hygiene among the rural community. $94.1 \%$ believed that skin disorder or infections are rising in India. $98.3 \%$ also perceived that spread of infections can be prevented using hygiene fabrics with herbal extract. $84.4 \%$ required antimicrobial product to improve their personal hygiene. When enquired about consumers' usage, $68.4 \%$ reported that they usually use antimicrobial product and most of them (60.3\%) preferred a smaller size product that is easy to carry. To find about their specific usage, consumers were asked to inform their typical use, and most of them [94.5\%] reported that they would use it for wiping face, hand, and other parts of the body.

The consumer's preference of sustainable and environmentally friendly product (made of organic or natural materials) was also probed and $89.2 \%$ preferred antimicrobial product that is made of organic source. $92.9 \%$ reported that they prefer a sustainable and environmentally friendly product. Generally, organic clothing is made from natural materials without chemicals and safe next to skin [47]. Consumer attitude is positively related to purchase intention of organic clothing. Consumer green consumption values affect their purchase intention as well as their attitude

\section{Venkatraman et al.,}


toward organic clothing [26]. 93.2\% believed that by purchasing sustainable products they contribute to the environment or society. It was also interesting to note that $93.1 \%$ preferred a re-usable product; $96.4 \%$ also preferred an economical product and $98.7 \%$ preferred a product that is easy to dispose and be biodegradable. The above finding contradicts previous research [13], which reported that professionals with improved awareness on environmental consciousness ('dark green apparel' consumers) were willing to pay for ecolabeled clothing.

The previous research [28] also noted that price and availability of product would enable consumers to get involved in organic clothing purchase. $77.5 \%$ rarely preferred product that is made of synthetic materials (polyester). When asked if they wish to re-use a product, majority of them (63\%) reported that they prefer to re-use twice or three times (15.6\%). This also suggests that consumers are desirous of a durable product that lasts longer as most consumers are eager to re-use the product. Generally, most consumers from India recycle and reuse clothing. Studies evaluating women's concern over environment affects their recycling behaviour and eagerness to purchase of organic clothing $[31,48]$. Research that studied key challenges and barriers to changing consumer attitude towards the purchase of sustainable clothing, suggested that not only providing information to consumer is essential but also ensuring it has a wider cultural and social context of their lives. In addition, ensuring that such products are easily available and encouraging reusage or repairing it, and increasing their longevity [49].

The consumer preferences of specific product attributes such as strength, softness, comfort, ability to wick moisture away, and the ability to stay fresh were also probed. Most of the participants [80.2\%] preferred a product that is durable and stronger; $98.7 \%$ preferred a product that is soft and comfortable next to the skin. $88 \%$ preferred a highly absorbent product and $96.7 \%$ preferred a product made of organic fibres such as cotton. This shows that consumers are specific in their preference when it comes to choosing their hygiene product. The product specific perception from consumers also show that their expectations are high, besides being environmentally friendly product and this finding is in line with other studies [7] that reported product should be appealing and product be soft in texture [31].

\section{DISCUSSION AND CONCLUSION}

The prior work which documented green behaviour had an influence on consumers green apparel buying behaviour, whilst Indian youth were not influenced by peers; consumers' green apparel knowledge did not influence their buying behaviour due to their limited knowledge on apparel manufacturing. Consumers who try to minimize negative impact on environment and their experience on using green products could become a predictor of Indian youth buying behaviour of green products [15]. Some study reported green attitude of consumer would influence green purchase intention. Indian consumer environmental knowledge is also influenced by government and non-government initiatives, and peer influence [50]. Other report added that Indian consumers' knowledge with an organic product influenced purchase; availability of organic clothing as a fashionable item would also influence purchase [28]. Consumers who have previous exposure to green products would act in an environmentally friendly manner [31]. However, these studies have either been looking at organic or green apparel alone or were not focused on hygiene textiles improving one's health resulting in a heterogenous literature. In this study, we evaluated the consumer perception on environmentally friendly antimicrobial on a group of participants [included various stakeholders healthcare workers, industry, etc.] from various Indian cities using a questionnaire.

The survey instrument developed to understand the current knowledge/awareness of consumer on rural health and issue in the community; awareness of sustainable and environmentally friendly textiles; and specific preferences on the usage of antimicrobial products identify consumers' specific requirements (product related attributes) has demonstrated high internal consistency as shown through Cronbach's alpha 0.87 . Factor analysis revealed four components with eigen values more than one, that explained $64.6 \%$ of the total variance. Questionnaire had shown strong loadings on component 1 with consumer awareness of sustainable product, its usage and preference on antimicrobial product price and quality; rural health and community issues items on component 2; product related attribute on component 3 and product reusability and awareness on rural health on component 4 . This demonstrated good scale reliability and relevance to the cohort studied. In addition, the structural equation model showed good fit and the hypotheses were well supported.

Our study indicates that consumers' awareness of rural health and hygiene could influence their knowledge and affect their purchase behaviour and majority prefer environmentally friendly antimicrobial textiles made of organic fibres with herbal finish to improve personal hygiene. Furthermore, our findings show that consumers believe that purchasing sustainable products they are contributing to the society or the environment. Consumers also preferred re-usable product, as opposed to disposable item, that is durable, economical, and easy to dispose and

\section{Venkatraman et al.,}


biodegradable. Mann-Whitney tests to determine any difference exists between genders showed no statistical significance indicating their perception on antimicrobial textiles remain similar.

These findings extend those of previous reports and therefore, indicate the benefit of evaluating consumer perception from a wide range of consumer group on environmentally friendly antimicrobial textiles that will facilitate stakeholders during design, development, and promotion of such eco-friendly antimicrobial textiles. Notably, this is the first study to our knowledge to address the importance of various attributes while determining consumer awareness and knowledge on sustainable textiles. This approach provides evidence on consumer group from five major cities in India indicating their specific preferences on eco-friendly antimicrobial textiles. However, there are some limitations within this research, including survey being a cross-sectional study, where the study collated

\section{REFERENCES}

[1] Gao, Y. and Cranston, R. 2008.Recent Advances in Antimicrobial Treatments of Textiles. Textile Research Journal, 78(1) 60-72

[2] Unicef (2019) Water, Environment and Sanitation, Unicef India. http://unicef.in/story/1125/waterenvironment -and-sanitation [accessed 14th Nov 2019]

[3] Narain J.P. 2016. Public Health Challenges in India: Seizing the opportunities, Indian J Community Med 2016 41(2): 85-88.

[4] WHO (2017) Vector Borne diseases WHO fact sheet,https://www.who.int/en/newsroom/fact-sheets/detail/vector-borne-diseases [accessed on 11th Nov 2019]

[5] Mehta, S.G. 2008. Eco-friendly textile now PET project for exporters. The Economic Times, April 7, Kolkata edition, 4 pp.

[6] Stern, N.Z. and Ander, W. N. 2008. Greentailing and Other Revolutions in Retail: Hot Ideas that are Grabbing Customers' Attention and Raising Profits. New Jersey: Wiley Publications

[7] Niinimäki, K. 2010.Eco-clothing, consumer identity and ideology. Sustainable Development, 18(3) 150-162.

[8] Berchicci L. and Bodewes W. (2005) Bridging environmental issues with new product development, Business strategy and environment 14(5)272-285

[9] Niinimäki, K. and Hassi, L. 2011. 'Emerging design strategies in sustainable production and consumption of textiles and clothing'. Journal of Cleaner Production. 19, 1876-1883.

[10] Kang, J., Liu, C. and Kim, S. 2013. Environmentally sustainable textile and apparel data only once from the consumers, had a smaller representative group from a population in India. Future studies should therefore include a follow up study on a larger representative cohort to explore whether consumers' perception retain over a longer period and, also to evaluate whether these aspects help to improve consumption of environmentally friendly textiles.

\section{Acknowledgements}

Authors would like to acknowledge the Global Challenges Research Fund obtained through Manchester School of Art and Research Centre [MSARC], Manchester Metropolitan University [MMU] (Project ID: 328682), which enabled to develop this collaborative research between Institute of Chemical Technology, ICT, India and MMU, UK. The Authors would also like to thank all the participants for responding to online survey. consumption: the role of consumer knowledge, perceived consumer effectiveness and perceived personal relevance'. International Journal of Consumer Studies, 37(4) 442-452.

[11] Lin, S-H. (2010). A case study in Hawaii: Who will pay more for organic cotton? International Journal of Consumer Studies, 34, 481-489.

[12] D’Souza, C., Taghian, M., Lamb, P. \&Peretiatko, R. 2007. Green decisions: demographics and consumer understanding of environmental labels. International Journal of Consumer Studies, 31, 204- 209

[13] Goswami, P. 2008. Is the urban Indian consumer ready for clothing with eco-labels? International Journal of Consumer Studies, 32(5) 438-446.

[14] Dhiman, R., Chand, P. and Gupta, S. 2018. 'Behavioural Aspects Influencing Decision to Purchase Apparels amongst Young Indian Consumers'. FIIB Business Review, 7(3) pp.188200.

[15] Khare, A. and Sadachar, A. 2017. Green apparel buying behaviour: A study on Indian youth. International Journal of Consumer Studies, 41(5) 558-569.

[16] Joshi, Y. and Srivastava, A. 2019. Examining the effects of CE and BE on consumers' purchase intention toward green apparels, Young Consumers, 21(2) 255-272.

[17] Ristić T., Zemljič L.F., Novak M., KunčičM.K.,et al., (2011) Antimicrobial efficiency of functionalized cellulose fibres as potential medical textiles, In: Science against microbial pathogens: communicating current research and technological advances, Editors: A. Méndez-

\section{Venkatraman et al.,}


Vilas, Publisher: Badajoz: Formatex Research Center.

[18] Glazer A.N., Nikaido H., 2007. Microbial Biotechnology: Fundamentals of Applied Microbiology, Cambridge: Cambridge Press

[19] Innovation in Textiles. 2019, Antimicrobial textiles market to reach $\$ 12.3$ billion; https://www.innovationintextiles.com/antimicr obial-textiles-market-to-reach-123-billion/ [Online resource accessed 06Jul 2020]

[20] Textile value chain (2020) Anti-viral clothing - a possibility? https://textilevaluechain.in/2020/08/20/antiviral-clothing-a-possibility/ [Online resource accessed 20 Aug 2020]

[21] India Textile Magazine, 2020Siyaram's launches Anti-Corona fabric in association with Australia-based

HealthGuardhttps://www.indiantextilemagazin e.in/corporate-news/s-launches-anti-coronafabric-in-association-with-australia-basedhealthguard/ [Online resource accessed $16^{\text {th }}$ Aug 2020]

[22] Kamal, N., 2020. Disinfectant masks being prepared by Trident Group to distribute among ruralites,

http://timesofindia.indiatimes.com/articleshow /75032154.cms?utm_source=contentofinterest \&utm_medium=text\&utm_campaign $=$ cppst [online resource accessed on $26^{\text {th }}$ Aug 2020]

[23] Ejemot-Nwadiaro R.I, Ehiri J.E., Arikpo D, Meremikwu MM, Critchley JA. 2015, Hand washing promotion for preventing diarrhoea. Cochrane Database of Systematic Reviews 2015, Issue 9. Art. No.: CD004265.

[24] Nagarajan R. 2020.Male or female, urban or rural, over $50 \%$ Indians 25 years or older; Times of

India,

http://timesofindia.indiatimes.com/articleshow /76759847.cms?utm_source=contentofinterest \&utm_medium=text\&utm_campaign=cppst [online resource accessed $21^{\text {st }}$ Aug 2020]

[25] Shivakumar, G. (2013) India is set to become the youngest country by 2020, Hindunewspaper, https://www.thehindu.com/news/national/indi a-is-set-to-become-the-youngest-country-by2020/article4624347.ece [Online resource accessed 19th Aug 2020]

[26] Varshneya, G., Pandey, S. and Das, G. 2017. 'Impact of Social Influence and Green Consumption Values on Purchase Intention of Organic Clothing: A Study on Collectivist Developing Economy'. Global Business Review, 18(2) pp.478-492.

[27] Khare, A. and Varshneya, G. 2017. Antecedents to organic cotton clothing purchase behaviour: study on Indian youth. Journal of Fashion
Marketing and Management: An International Journal, 21(1) 51-69.

[28] Khare, A., Sadachar, A. and Manchiraju, S. 2019. Investigating the Role of Knowledge, Materialism, Product Availability, and Involvement in Predicting the Organic Clothing Purchase Behavior of Consumers in the Indian Market.Journal of International Consumer Marketing, 32(3) 228-242.

[29] Gupta, M. and Hodges, N. (2012), Corporate social responsibility in the apparel industry. Journal of Fashion Marketing and Management: An International Journal, 16(2) pp.216-233.

[30] Cotton Incorporated's Global Lifestyle survey 2016. Cotton council International and cotton Incorporated Global Lifestyle monitor survey, Global consumer insights: India

https://lifestylemonitor.cottoninc.com/globalconsumer-insights-india/ [online resource accessed 17th Aug 2020]

[31] Gam, H., Cao, H., Farr, C. and Kang, M. (2010) 'Quest for the eco-apparel market: a study of mothers' willingness to purchase organic cotton clothing for their children'. International Journal of Consumer Studies, 34(6) 648-656.

[32] Gupta D., Singh R., Jain, Panwar, Khare S.K., 2005. Antibacterial activity of some natural dyes, Dyes and Pigments, 66(2) 99.

[33] Joshi, M., Ali, S. and Rajendran, S. 2007. Antibacterial finishing of polyester/cotton blend fabrics using neem (Azadirachta indica): A natural bioactive agent. Journal of Applied Polymer Science, 106(2) pp.793-800.

[34] Thilagawathi G. and Rajendrakumar K. (2005) Development of eco-friendly anti-microbial textile finishes using herbs, Indian Journal of Fibre and Textile Research, 30, 431-436

[35] Sathianarayanan M.P., Bhat, N.V., Kokate S.S., and Walunj V.E. 2010. Antibacterial finish for cotton fabric from herbal products, Indian Journal of Fibre \& Textile Research, 35:50-58

[36] Rajendran, R., Radhai, R., Kotresh, T. and Csiszar, E. 2020. Development of antimicrobial cotton fabrics using herb loaded nanoparticles.

[37] Pallant, J. F. 2000. Development and validation of a scale to measure perceived control of internal states. Journal of Personality Assessment, 75(2), 308-337.

[38] De Villis, R. F. 2003. Scale development: Theory and applications (2nd ed.). Thousand Oaks, CA: Sage Publications.

[39] Kline, R. B. 2005. Principles and practice of structural equation modelling (2nd ed.). New York: Guildford.

\section{Venkatraman et al.,}


[40] Hair, J. F., Black, W. C., \&Babin, B. J. 2010. Anderson Multivariate data analysis: A global perspective. New Jersey, Pearson Prentice Hall

[41] Kaiser, H. F. (1974). An index of factorial simplicity. Psychometrika, 39, 32-36.

[42] Tabachnick B.G. and Fidell L.S. 2007. Using multivariate statistics. $5^{\text {th Edn. }}$ Boston, MA: Pearson Education Inc.

[43] Chan, L. and Idris, N. 2017. Validity and Reliability of The Instrument Using Exploratory Factor Analysis and Cronbach's alpha. International Journal of Academic Research in Business and Social Sciences.7 (10) pp:400-410

[44] Arbuckle JL 2017. IBM SPSS AMOS Users guide., Amos Development Corporation

[45] Hooper, D., Coughlan, J. and Mullen, M. R.2008. "Structural Equation Modelling: Guidelines for Determining Model Fit." The Electronic Journal of Business Research Methods 6 (1) 53-60.
[46] Laerd Statistics 2015. Cronbach's alpha using SPSS Statistics. Statistical tutorials and software guides. Retrieved from https://statistics.laerd.com/

[47] Hustvedt, G., Dickson, M.A. 2009. Consumer likelihood of purchasing organic cotton apparel. Journal of Fashion Marketing and Management, 13(1), 49-65

[48] Lin, S. 2009. Exploratory evaluation of potential and current consumers of organic cotton in Hawaii. Asia Pacific Journal of Marketing and Logistics, 21, 489-506.

[49] Harris, F., Roby, H. and Dibb, S. 2015.Sustainable clothing: challenges, barriers and interventions for encouraging more sustainable consumer behaviour. International Journal of Consumer Studies, 40(3) pp.309-318.

[50] Kumar, R., Saha, R., P.C., S. and Dahiya, R. 2019. Examining the role of external factors in influencing green behaviour among young Indian consumers'. Young Consumers, 20(4) pp.380-398. 